\title{
LINGUAGEM AUDIOVISUAL E INSURGÊNCIAS POPULARES: RECONSTITUINDO UMA EXPERIÊNCIA ASSOCIATIVA ENTRE JOVENS VÍDEO-ATIVISTAS NAS “PERIFERIAS" PAULISTANAS
}

\author{
Guilhermo Aderaldo ${ }^{1}$
}

\begin{abstract}
Dentro da cultura, a marginalidade, embora permaneça periférica em relação ao mainstream, nunca foi um espaço tão produtivo quanto é agora, e isso não é simplesmente uma abertura, dentro dos espaços dominantes, à ocupação dos de fora. É também o resultado de políticas culturais da diferença, de lutas em torno da diferença, da produção de novas identidades e do aparecimento de novos sujeitos no cenário político e cultural (Hall, 2009 [2003]: 320).
\end{abstract}

\section{Introdução ${ }^{2}$}

Na primeira década dos anos 2000, mediante a significativa evolução das tecnologias digitais e a consequente popularização do acesso a uma variedade de dispositivos de comunicação (smartphones, câmeras, computadores, etc.), diversas iniciativas sustentadas, principalmente por ONGs, passaram a formar, em cursos e oficinas de produção audiovisual, populações residentes de áreas periféricas dos grandes centros urbanos brasileiros ${ }^{3}$.

A maior parte dessas experiências de formação baseou-se (e ainda se baseia) na justificativa da importância de fornecer a um público historicamente negligenciado ou sub representado pelas narrativas "oficiais" e/ou hegemônicas, condições para a elaboração de formas alternativas de representação do mundo social.

\footnotetext{
${ }^{1}$ Universidade de São Paulo, Brasil; Universidade de Buenos Aires, Argentina.

${ }^{2}$ Aproveito este espaço para agradecer especialmente à FAPESP, pelas bolsas de doutorado (Processo $\mathrm{N}^{\mathrm{o}}$ 09/50153-9) e pós-doutorado (2014/04243-8) responsáveis pelo oferecimento das condições para a reflexão que dá lugar ao presente texto. Da mesma forma sou grato aos colegas do Grupo de Estudos de Antropologia da Cidade (GEAC/USP) e do Laboratoire d'Anthropologie Contemporaine (LAC/EHESS), pelas importantes trocas e aprendizados coletivos construídos ao longo dos últimos anos.

${ }^{3}$ Citando apenas algumas instituições que costumam desenvolver este tipo de atividade, em diferentes Estados, temos: Associação Cultural Kinofórum, Instituto Sampa.Org, Instituto Criar, Ação Educativa, Central Única das Favelas (CUFA), Associação Cidadela, Associação Imagem Comunitária (AIC), Centro de Ações Solidárias da Maré (CEASM), Projeto Arrastão, entre outras. É importante lembrar, porém, que há diferenças consideráveis tanto nos projetos quanto nos princípios que guiam cada uma dessas instituições. Algo que, por sua vez, as faz contar com mais ou menos credibilidade entre os sujeitos que serão apresentados no decorrer deste artigo.
} 
Em pouco tempo, uma expressiva trama institucional passou a orbitar em torno do campo das produções audiovisuais entendidas, de forma genérica, como "periféricas". Surgiram assim, festivais, mostras e distintas linhas de financiamento público e privado ${ }^{4}$ voltadas a fomentar um modelo de produção audiovisual que passou a receber diferentes nomenclaturas, a depender da forma como a alteridade é percebida e representada em cada caso. "Cinema de Periferia", "Cinema de Favela", "Cinema Comunitário", "Cinema Comunitário Jovem", "Vídeo Popular", "Vídeo Independente”, “Cinema Divergente" e "Cinema de Quebrada" são, por exemplo, algumas das rubricas utilizadas nessa tentativa de caracterização.

Porém, ainda que de forma menos visível, um outro processo correu em paralelo a essas transformações no âmbito institucional. Refiro-me, mais especificamente, ao fato de que, após adquirirem a expertise técnica necessária para a realização de produções audiovisuais mais elaboradas, parte significativa dos realizadores egressos dessas oficinas e cursos de formação audiovisual vinculados a "projetos sociais", passou a buscar formas de autonomização em relação às ONGs e a todo o universo corporativo direta ou indiretamente ligado a essas organizações.

Muitas dessas pessoas, sobretudo aquelas com maior capital escolar ou com histórico de participação em movimentos de luta popular, tomaram a iniciativa de se associarem em "coletivos" dedicados à produção e exibição independente de vídeos, sendo que as oportunidades para o desenvolvimento desta forma de associativismo foram especialmente incentivadas por um conjunto de políticas voltadas ao fomento de iniciativas culturais protagonizadas, sobretudo, por populações "jovens" e habitantes de regiões periféricas e/ou carentes de equipamentos culturais, cuja principal referência, no caso de São Paulo é, até os dias atuais, o Programa Para a Valorização às Iniciativas Culturais (VAI), lançado em 2003, sob a forma de lei $\left(\mathrm{N}^{\mathrm{o}}\right.$ 13.540), pela Secretaria Municipal de Cultura ${ }^{5}$.

\footnotetext{
${ }^{4}$ Cabe ressaltar, no entanto, que os financiamentos privados são, quase sempre, baseados na garantia de subsídios públicos, via exonerações fiscais.

${ }^{5}$ A referida lei municipal destaca-se por privilegiar agrupamentos não formalizados juridicamente, o que significa que as verbas são repassadas diretamente aos coletivos contemplados, sem a necessidade de intermediários, através de um dos membros que se inscreve na condição de "proponente". O uso desses subsídios, que posteriormente devem constar em uma prestação de contas ao município, pode ser alocado de muitas maneiras, como na aquisição de equipamentos comprovadamente essenciais para a execução do projeto. Mais informações em: http://programavai.blogspot.com.br (Acessado em 18/05/2017).
} 
A maior parte dos realizadores integrados nesses coletivos é formada por jovens na faixa entre os 18 e 35 anos os quais, além do domínio técnico no manejo de instrumentos audiovisuais, são amplamente "conectados" e possuem um repertorio múltiplo de referências culturais e estéticas. Os mesmos, em geral, atuam profissionalmente - e de forma bastante precária e irregular - nas chamadas "profissões criativas". Assim, se encontram constantemente disputando editais voltados ao financiamento de atividades culturais, ao mesmo tempo em que exercem funções como a de arte educadores, cinegrafistas, editores de vídeo e fotógrafos, quase sempre a partir da prestação de serviços ocasionais a diferentes instituições ou a pessoas que podem contrata-los para pequenos trabalhos esporádicos.

A despeito da precarização laboral, esses jovens fazem parte de uma geração que, de algum modo, se beneficiou de uma relativa melhoria nas condições de vida e na capacidade de consumo das camadas socialmente desprivilegiadas, por conta de um conjunto de mudanças políticas e econômicas que marcaram a história recente do país. Muitos, por exemplo, compõem a primeira geração de suas famílias a conseguir o ingresso em instituições de ensino superior (alguns, inclusive, em universidades públicas $)^{6}$.

Todavia cabe notar que, em muitos casos, a organização em torno de coletivos e a busca de uma relativa autonomia em relação às ONGs, traz em seu cerne uma atitude de interpelação crítica à forma pela qual tais organizações e sua linguagem, baseada no princípio da "responsabilidade social", costumam representar as populações e territórios marginalizados.

O acúmulo de experiências educativas e profissionais junto a essas organizações, não raro, leva muitos desses jovens realizadores a uma conclusão semelhante quanto ao modo pelo qual sua "diferença" passa a ser capitalizada num poderoso "mercado cultural" o qual, na visão destes, tende a silenciar a potencialidade emancipatória das reivindicações populares que estimulam a realização de muitos de seus vídeos, na medida em que tais instituições, comumente, se valem de um léxico responsável pela transformação de problemas de natureza política em questões morais, vinculadas a uma lógica "compassiva" e "humanitária” (Fassin, 2014). Colocando em outras palavras, isso significa que, ao invés de serem pensados como "sujeitos políticos" reivindicando

\footnotetext{
${ }^{6}$ A respeito dessas transformações na vida das populações de baixa renda e suas consequências nas formas de mobilidade social e urbana ver, particularmente, Caldeira (2012), Valladares (2010) e Marques (2015).
} 
direitos, esses agentes acabam, amiúde, sendo caracterizados no esquema interpretativo de uma série de instituições do chamado "terceiro setor", na chave das "vítimas" da “exclusão social”, em busca de "oportunidades” no mercado cultural hegemônico.

Buscando, então, atribuir visibilidade a essas disputas simbólicas e seus desdobramentos políticos na esfera pública, a proposta deste artigo será a de reconstituir etnograficamente o processo de formação e desenvolvimento do Coletivo de Vídeo Popular (CVP). Uma rede descentralizada, integrada por uma diversidade heterogênea de coletivos dedicados ao chamado vídeo-ativismo na capital paulista, a qual acompanhei, de maneira mais detida, entre os anos de 2009 e 2013 e cujo principal interesse foi, durante o período pesquisado, a consolidação de um sistema de comunicação capaz de integrar politicamente e de forma independente de vínculos institucionais, distintas regiões e populações "marginalizadas" da cidade". Tentarei, desta forma, demonstrar como a proliferação do uso de tecnologias comunicativas tem aberto novas frentes de reconhecimento, sociabilidade e luta política, sobretudo, para populações jovens e historicamente desprivilegiadas no mundo urbano contemporâneo.

\section{Entre imagens e imaginários: percursos e dissidências estéticas/políticas}

Em meados de 2011, durante uma conversa a respeito do processo de formação e consolidação do coletivo Núcleo de Comunicação Alternativa (NCA) - uma associação informal, surgida no ano de 2005, logo após seus três membros fundadores terem passado por cursos de educação audiovisual oferecidos por distintas ONGs na capital paulista $^{8}-$ Fernando Solidade, um dos integrantes do coletivo, disse-me as seguintes palavras:

\footnotetext{
7 A referida pesquisa, defendida como tese de doutorado no departamento de antropologia social da Universidade de São Paulo em 2013, atualmente está publicado como livro. Para mais detalhes ver Aderaldo (2017).

${ }^{8}$ Antes de formarem o NCA, Daniel Fagundes, Diego Soares e Fernando Solidade, os três membros fundadores do referido coletivo, passaram por cursos e oficinas de formação audiovisual que haviam sido oferecidos, respectivamente, pelas ONGs Associação Cultural Kinofórum, Instituto Sampa.Org e Ação Educativa em distintos locais de São Paulo. Posteriormente, os mesmos desenvolveram trabalhos esporádicos para muitas outras instituições, o que gerou um conhecimento bastante acentuado sobre os métodos e princípios por trás da atuação das mesmas, assim como sobre toda a economia política que orienta tais projetos, num universo mais amplo de interlocuções institucionais.
} 
(...). Foi discutindo a questão sobre o imaginário e não as imagens que a gente começou a notar a importância da nossa produção [audiovisual]. Foi a hora que a gente começou a ficar puto com as ONGs porque elas vinham com esse papinho bonitinho de que "os jovens agora fazem suas próprias imagens", "os jovens agora contam sua própria história", como se alguma chave no processo histórico estivesse sendo mudada (...). As ONGs se colocam muito como os protagonistas dessa cena. Esse discurso: "nós possibilitamos que os jovens da periferia pudessem contar sua história, estão vendo o que a gente fez? " Começou a irritar. A gente começou a ficar muito decepcionados e nos questionar: mas que porcaria de imaginário a gente está mudando? (Fernando Solidade, coletivo NCA, entrevista ao autor, grifos meus).

A fala de Fernando traz em seu conteúdo o produto de uma reflexão partilhada por muitos jovens egressos dos mesmos cursos de formação audiovisual pelos quais ele e seus colegas de NCA haviam passado. Por um lado, esses jovens reconheciam que a circulação por essas oficinas e cursos foi extremamente benéfica pelo fato de fornecer um conjunto de conhecimentos que, posteriormente, se revelariam importantes em termos profissionais e políticos. Por outro lado, no entanto, os mesmos costumavam criticar duramente várias instituições responsáveis pelo oferecimento desses cursos para populações entendidas como "periféricas", devido ao modo como, em muitos casos, noções estereotipadas e moralizantes de termos como "periferia" e "favela", acabavam sendo reproduzidas, uma vez que os espaços urbanos marcados por processos de precarização eram comumente tratados como ambientes isolados, homogêneos e/ou marcados por uma problemática especificidade cultural.

As ONGs pelas quais os integrantes do NCA haviam transitado - seja na condição de educandos, seja atuando, esporadicamente, como educadores ou prestadores de serviços -, gradualmente, começaram a ser compreendidas pelos mesmos como a ponta de um grande "mercado", que se alimenta de um modelo interpretativo responsável por representar as populações residentes de áreas urbanas precárias na condição ontológica de "vítimas". O que significa dizer que estas são, quase sempre, descomplexificadas ao serem representadas como "o outro" da "cidade". Ou seja, como aqueles que vivem eternamente à espera de "oportunidades" e cuja imagem poderia ser largamente explorada por uma variedade de empresas baseadas na lógica da, assim chamada, "responsabilidade social".

A crítica a esse tipo de representação das populações "periféricas" e seus efeitos de poder torna-se ainda mais clara através de palavras como as de Daniel Fagundes, outro membro do coletivo NCA, ao dizer que: 
Os caras, principalmente dessas oficinas [de vídeo], vieram com essa coisa de que todo mundo já falou de favela e agora eles estavam trazendo essa ideia de que dariam o direito da gente falar, mas eles vendem, sabe? Era isso, eles vendiam a oficina. Eles tinham a aquisição dos equipamentos e a gente tinha o olhar, que depois virava uma propaganda para as próprias instituições, não é? Eu era aquele menininho que vinha com o carimbo do Itaú, da Camargo Correia e eles iam carimbando porque depois a gente virava dado para as próprias propagandas do Itaú, onde eles diziam [imita]: "Olha, o Itaú apoia o jovem da quebrada que saiu com a câmera na mão" (Daniel Fagundes, coletivo NCA, Entrevista ao autor, Grifos meus).

O principal ponto do questionamento desses jovens àquilo que identificam como "marketing social", portanto, é o sentimento de que a potencialidade política de seus vídeos acaba esvaziada na medida em que as apostas institucionais, muito frequentemente, resvalam na reprodução da imagem reificada das favelas e periferias, dado que esses territórios costumam ser entendidos como universos simbólicos a terem sua "estética própria” traduzida nos termos da indústria cultural hegemônica.

Para eles, o problema de tal postura consiste no fato de que ela leva a um tipo de atuação mais concentrado na tentativa de criar comunicação através de fronteiras supostamente fixas e estáveis (entre um "centro" e uma "periferia", entendidos de modo autoevidente) do que na busca por uma real interpelação das forças que geram e administram as desigualdades responsáveis pela sustentação de tais espaços liminares. Atitude que, por sua vez, contribui para o desenvolvimento de um amplo mercado cultural voltado à determinada representação estética e reificada das "periferias" sem que para isso seja necessário refletir mais profundamente a respeito de uma série de desigualdades e violências políticas que costumam acometer os habitantes dessas regiões, na medida em que os mesmos passariam a serem vistos como portadores de uma "cultura própria" 9 .

\footnotetext{
${ }^{9}$ Colocando em outros termos, o debate sobre "diversidade cultural" acaba, frequentemente, se sobrepondo ao debate sobre o problema da "desigualdade" no campo do acesso aos direitos. Tal questão vem sendo largamente discutida por outros trabalhos recentes sobre o tema da relação entre juventude e politicas culturais. Neste sentido, cabe mencionar trabalhos como os de Souza (2008) e De Tommasi (2016), que apontam para o modo como certas políticas e projetos culturais tem buscado converter os antigos "jovens problema", alvo de ações profiláticas, no que as autoras ironicamente denominam como "jovens solução", ou seja, em "técnicos nativos" de ONGs e instituições governamentais voltadas a estratégias de "desenvolvimento" local. Conforme destaca Yúdice (2013), uma das características centrais de nosso tempo, refere-se, justamente, ao fato de que a "cultura" tem sido, com muita frequência, convertida num instrumento utilizado como "recurso" para outros fins (políticos, econômicos, securitários). Segundo o autor, tal fato tem levado a que a diferença se torne um valor, capaz de acionar um suposto prestígio da identidade de "minorias culturais", multiplicando, assim, mercadorias, muitas vezes englobadas nos termos da indústria cultural hegemônica. Desta maneira, produzir-se-ia continuamente, um tipo de "diferença" que não faz a diferença.
} 
Além disso, com o passar do tempo e o significativo alargamento de suas experiências citadinas ${ }^{10}$, alguns desses jovens realizadores também passaram a questionar o próprio modo como sua mão de obra costumava (e ainda costuma) ser absorvida por esse "mercado cultural periférico", uma vez que é algo comum os mesmos serem, por exemplo, subcontratados por diversas instituições - ganhando muito pouco e sem poderem contar com nenhum tipo de registro profissional -, para fazerem trabalhos decorrentes de alta especialização técnica, sendo que, repetidas vezes, a atribuição identitária de "jovens de periferia" acaba utilizada como um modo de aferir credibilidade às "boas ações" de uma miríade de organizações, ao mesmo tempo em que oculta a diversidade de relações de exploração que os afetam de forma muito direta.

Neste caso, é interessante notar como a própria noção de "juventude", ao ser combinada com representações estereotipadas do termo "periferia", desdobra-se num imaginário que tende a ampliar a condição de subordinação daqueles que passam pelos “projetos sociais", uma vez que "ser jovem" aqui, a exemplo do que mostra Debert (2010), pode implicar num valor que tende a reproduzir a ideia de que não se está capacitado a alcançar um estágio da vida marcado pela maturidade, responsabilidade e compromisso. Assim, a alcunha de "jovem morador da periferia" acaba servindo como um modo de manter esses atores sempre na posição de "aprendizes" e, com isso, fazer com que o valor de seu trabalho seja, consideravelmente, rebaixado em comparação a outros profissionais "mais experientes".

Foi pensando nisso que os mesmos integrantes do NCA escreveram um texto intitulado "Uma educação curta para vídeos curtos", o qual foi inicialmente publicado no blog do coletivo tendo, posteriormente, figurado como um dos capítulos do livro comemorativo de 10 anos da ONG Associação Cultural Kinofórum ${ }^{11}$. Num dos trechos do referido texto, lemos a seguinte passagem:

\footnotetext{
${ }^{10}$ Refiro-me aqui ao acúmulo de experiências como a atuação em diferentes movimentos de luta popular, o ingresso em instituições de ensino superior e o trabalho simultâneo em distintas organizações do "terceiro setor".

${ }^{11} \mathrm{Na}$ ocasião, a ONG convidou alguns dos jovens que haviam participado das oficinas ministradas pela mesma para que narrassem suas experiências com o vídeo durante e após a formação. No texto, os integrantes do coletivo reconhecem a importância da Kinofórum e outras instituições na obtenção de conhecimentos, mas, como vemos, não deixam de criticar um tipo de pensamento que tende a pensa-los apenas como "produto" da atividade destas organizações. A versão completa do livro pode ser lida no seguinte endereço: https://issuu.com/kinoforum/docs/vi_vendo (Acessado em 27/05/2017).
} 
O tempo e as escolhas que fizemos não foram compatíveis com as exigências de mercado. Primeiro porque, por mais que nesse período todo de existência do grupo [Referência ao NCA] tenhamos nos especializado e atualizado, o trabalho na área [Audiovisual] sempre nos foi precário. Quando não tínhamos recursos dos editais de baixíssimo orçamento como o VAI e outros do Governo Federal, o que nos restava eram os trabalhos em "parceria" com as ONGs, onde a regra era sempre pouca verba para muito trabalho e muitas exigências e, quando mesmo essas alternativas eram escassas, o terceiro setor era quem nos acolhia (como aquela mãe que põe os filhos no farol para mendigar). Segundo, porque a acessibilidade ao conhecimento e a equipamentos necessários à produção nos foi por muitas vezes negada. A teima nos trouxe aqui, não as ONGs. Para as ONGs, por mais que negássemos esse rótulo, nós sempre fomos os filhos rebeldes do seu ventre. Os meninos que deram "certo". Mas a única certeza que nós sempre tivemos, mesmo antes das primeiras oficinas de formação, era que, vindo de onde viemos, tudo seria mais complicado. Afinal, nossas mães diaristas nunca puderam bancar $\mathrm{FAAP}^{12}$ para que nos formássemos para a inserção na pequena brecha do mercado audiovisual (Núcleo de Comunicação Alternativa, 2012: 98-99, grifos meus)

Foi, portanto, pensando na dificuldade de uma efetiva inserção profissional no campo do audiovisual, bem como no processo de precarização laboral e nas representações - muitas vezes estereotipadas - dos ambientes socialmente marginalizados, que costumavam circular nas ONGs, festivais e circuitos vinculados às produções realizadas no contexto dos "projetos sociais", que muitos desses jovens, egressos de cursos e oficinas de formação, passaram a entender a importância do uso político e pedagógico dessas ferramentas.

Deste modo, paulatinamente, a partir de encontros (e alguns desencontros) que se davam em espaços comuns de sociabilidade - como associações culturais, saraus, mostras, festivais e sedes de ONGs - um conjunto de pessoas que vinha participando de maneira muito ativa desse campo, começou a discutir a necessidade de uma virada narrativa e estética nas produções audiovisuais entendidas como "periféricas" ou "populares".

Para boa parte dessas pessoas, tornava-se cada vez mais necessário fazer filmes que pudessem, por um lado, 1) se esquivar de uma apreensão ingênua e "mercadológica" de noções como "favela" e "periferia", deixando de assumir esses conceitos como categorias identitárias fixas, homogêneas e autoevidentes e, por outro, 2) questionar os princípios do próprio mercado cultural centrado na estetização moralizada desses territórios. E foi em torno dessa discussão que nasceu a rede Coletivo de Vídeo Popular (CVP), cujos passos buscarei reconstituir a partir do tópico seguinte.

\footnotetext{
12 Referência à Fundação Armando Alvares Penteado (FAAP). Uma das instituições particulares de ensino conhecidas, tanto pela qualidade dos cursos, quanto pelo alto valor das mensalidades.
} 


\section{Entre o "mercado da periferia" e a "periferia" do mercado: o Coletivo de Vídeo Popular (CVP) e sua lógica reivindicativa}

Conforme adiantei, a rede conhecida como Coletivo de Vídeo Popular (CVP) surgiu nos bastidores de uma série de encontros (e desencontros) que vinham ocorrendo entre pessoas interessadas no uso político de ferramentas audiovisuais, sobretudo, entre aqueles que integravam coletivos como o supracitado NCA, os quais se multiplicavam em regiões periféricas de São Paulo, principalmente após o lançamento do já mencionado programa $\mathrm{VAI}^{13}$.

Nas conversas que costumavam ocorrer entre essas pessoas, tornava-se evidente certa insatisfação em relação ao fato de sentirem que não possuíam representatividade política, justamente por terem suas falas e posicionamentos quase sempre subordinados às ações administrativas de agentes ligados a organizações do "terceiro setor". Conforme me disse Wilq Vivente, um dos atores diretamente envolvidos no processo de formação do CVP, em uma conversa pessoal: "os caras das ONGs falavam pela gente. Eles falavam o que queriam e a gente ficava sempre nesse papel passivo de 'meninos da periferia'. A gente legitimava as ações deles e ficava sem autonomia nenhuma”.

Foi, portanto, a partilha desse sentimento de desamparo e falta de representatividade pública, o fator responsável por estimular a consolidação de vínculos associativos independentes dos emaranhados institucionais; o que, todavia, não significou um rompimento radical com as ONGs, pois as reuniões dessa rede ocorriam, muitas vezes, nos espaços cedidos por algumas delas. Além disso, certos membros do CVP trabalhavam e/ou possuíam fortes laços de amizade com pessoas que integravam os quadros profissionais de diferentes ONGs na cidade. Também diferenciavam instituições que contavam com maior credibilidade e outras que, ao contrário, não possuíam quase nenhum reconhecimento, sendo entendidas como entidades meramente "assistencialistas".

Desse modo, a principal ideia por trás da formação da rede CVP foi a de construir um espaço relativamente independente de trocas e intercâmbios de produções e reflexões entre coletivos culturais dedicados, prioritariamente, à produção, formação e exibição de linguagens audiovisuais politicamente engajadas nas áreas periféricas da cidade, com o objetivo de enfrentar, basicamente, cinco desafios comuns, que eram:

\footnotetext{
${ }^{13}$ Para uma visão mais detida sobre a importância do Programa VAI no processo de multiplicação de coletivos culturais nas periferias de São Paulo ver Aderaldo (2017), particularmente o capítulo 2.
} 
1. Construir uma rede comunicativa esquiva às formas tradicionalmente utilizadas pelas empresas jornalísticas vinculadas a grupos corporativos, bem como às instituições do terceiro setor e mais próximo de movimentos de luta popular;

2. Possibilitar uma leitura conjunta das causas sociais relacionadas aos problemas que atingem distintas regiões urbanas precárias (especulação imobiliária, desapropriações, desigualdade de direitos, etc.), com vistas a produzirem e exibirem filmes relacionados a estes temas;

3. Estimular a circulação dos realizadores e exibidores de filmes politicamente orientados por toda a cidade, tornando-os reconhecidos em uma extensa rede de circuitos de exibição, a serem construídos por ações populares em lugares estratégicos (favelas, bares, campos de futebol amador, ocupações culturais e habitacionais, escolas da rede pública, etc.);

4. Ocupar e legitimar, com a exibição de filmes e a realização de debates, espaços abandonados pelos poderes públicos;

5. Sustentar uma representação autônoma (desvinculada de interesses institucionais) dos coletivos de realizadores audiovisuais comprometidos com causas sociais na cidade junto aos poderes públicos ligados à cultura e à gestão urbana, com a finalidade de influenciar processos de formulação de políticas públicas para os setores audiovisual e urbano.

Um dos principais articuladores da formação desta rede foi o realizador audiovisual e educador social Diogo Noventa. Diogo integrou a equipe de professores responsáveis pelo curso "Vídeo, Cultura e Trabalho (VCT)", o qual foi realizado entre os anos de 2004 e 2006 pela ONG Ação Educativa ${ }^{14}$.

Na contramão das oficinas de formação ministradas pela maioria das ONGs, o curso VCT tinha a especificidade de uma longa duração (2 anos). Também contava com uma parte das aulas voltadas à discussão de temas políticos e sociais, para além da formação técnica na elaboração de vídeos. E foi durante este curso que, por exemplo, Daniel Fagundes, Diego Soares e Fernando Solidade se conheceram e idealizaram a formação do mencionado coletivo NCA.

O curso VCT era dividido entre as linhas de "cultura", relacionada às aulas com conteúdo mais técnico, voltadas ao ensino da manipulação de ferramentas audiovisuais e artísticas e "trabalho", cujas aulas versavam sobre questões relativas à temas como “cidadania", "relações políticas na cidade", etc.

\footnotetext{
${ }^{14}$ Algumas informações mais detalhadas sobre o curso Vídeo, Cultura e Trabalho (VCT) podem ser obtidas em: http://acaoeducativa.org.br/antigo/index.php/juventude/37-juventude-e-participacao/260juventude (Acessado em 03/05/2017).
} 
Entre as aulas, a de Diogo Noventa tinha uma particularidade, pois o educador trabalhava com a análise de filmes de diretores voltados a um cinema politicamente engajado, como Glauber Rocha e Serguei Eisenstein, à luz das reflexões de autores marxistas. Nessa altura ele também atuava juntamente com sua esposa - a atriz Juliana Liegel - na formação de uma companhia de teatro vinculada à linguagem audiovisual chamada Companhia Estudo de Cena.

Porém, com o desenvolvimento das aulas, sua postura "engajada" e pouco afinada com certos princípios relacionados ao curso na ONG onde trabalhava, ficou cada vez mais clara, o que gerou alguns conflitos internos que foram, pouco a pouco, minando sua posição na instituição. Nas palavras do educador:

\begin{abstract}
Para mim não tinha muito essa discussão de periferia. Na verdade, eu não fazia essa discussão de periferia, eu fazia uma discussão de classe. Não importava se o cara era da periferia ou não. O VCT tinha esse recorte, mas eu não levava em conta. Eu acho que isso daí foi muito legal também porque gerou uma empatia muito grande entre eu e os alunos, porque não tinha um tratamento para "público de periferia" (...) (Diogo Noventa, educador e membro da Cia. Estudo de Cena, entrevista ao autor).
\end{abstract}

Segundo Diogo, portanto, a falta de sintonia entre sua postura como educador/militante e alguns dos princípios institucionais da ONG onde atuava foi o que levou à sua saída da organização. Isso, porém, ao contrário de inibi-lo, estimulou seu desejo de aprofundar seus estudos sobre vídeo popular, bem como de estreitar os laços com algumas das pessoas que havia conhecido ao longo do período em que trabalhou no VCT.

Foi então que, em 2006, ele ofereceu um curso sobre a "História do Vídeo Popular no Brasil", no Centro Cultural e de Estudos Superiores Aúthos Pagano ${ }^{15}$, localizado no bairro do Alto da Lapa, em São Paulo. Diversas pessoas que vinham utilizando a linguagem audiovisual como ferramenta de ação política em projetos colaborativos na cidade participaram do referido curso, incluindo muitos alunos egressos do VCT que, conforme mencionado, começavam a se associar, de maneira independente, em diferentes coletivos dedicados à produção e exibição audiovisual. Segundo Diogo:

\footnotetext{
${ }^{15}$ Ver: http://www.centroculturalauthospagano.org.br/apresentacao/ (Acessado em 16/05/2017).
} 
Nesse curso juntou muita gente. Veio o Fernando do coletivo NCA, veio a Juliana do coletivo Cine Becos, veio o Felipe da Brigada Audiovisual da Via Campesina [setor responsável pelas produções audiovisuais do MST], veio o pessoal do coletivo Favela Atitude, veio o Evandro, do coletivo Nossa Tela, enfim, o pessoal que veio a formar o Coletivo de Vídeo Popular. Então foi um momento importante, quando a gente juntou aquela galera e foi um estudo muito importante porque eu consegui falar da história do vídeo desde a vídeo-arte até a relação com o cinema russo pela $\mathrm{ABVP}^{16}$. Foi todo mundo mostrando suas produções e a gente foi debatendo os conteúdos. E a gente fechou o curso com o Luiz Fernando Santoro indo lá conversar com a gente (Diogo Noventa, educador e membro da Cia. Estudo de Cena, entrevista ao autor, grifos meus).

Foi em meio a essas interlocuções entre atores vinculados a múltiplas e heterogêneas filiações associativas e igualmente interessados no uso da produção audiovisual como ferramenta de enunciação política que os contatos sociais, os interesses e os "projetos" (Velho, 2004 [1987]) $)^{17}$ dos jovens que haviam se formado nos cursos e oficinas de vídeo oferecidos por distintas ONGs na cidade começaram a se diversificar consideravelmente. Além disso, boa parte dessas pessoas, como adiantei, também ingressaram em cursos universitários (de graduação e pós-graduação) neste mesmo período, o que as ajudou a refletirem melhor sobre suas posições e o sentido de suas produções.

Tal densidade de relações e a iniciativa de uma articulação em rede, a partir da formação do CVP, tornaram-se ainda mais fortes após o surgimento do Fórum de Experiências Populares em Audiovisual (FEPA). Uma rede formada quase exclusivamente por gestores de ONGs dedicadas a projetos de educação audiovisual junto a minorias étnicas ou populações residentes de regiões marginalizadas em todo o país, cuja proposta era representar os interesses das chamadas "experiências populares em audiovisual", em meio aos setores responsáveis pela constituição de políticas públicas voltadas à cultura (com ênfase ao campo audiovisual) nas distintas esferas da federação.

\footnotetext{
${ }^{16}$ A Associação Brasileira de Vídeo Popular (ABVP) foi uma entidade, fundada em 1984, num contexto marcado por diversas greves operárias no Brasil. O objetivo da ABVP foi incentivar iniciativas de capacitação e distribuição de informações entre as camadas populares do país, uma vez que estas populações costumavam ser negligenciadas pela grande mídia. Também buscava-se uma aproximação junto aos movimentos sociais e populares. A organização durou duas décadas, consolidando-se como uma das principais experiências de luta pela democratização da comunicação no Brasil. Uma de suas principais lideranças foi Luiz Fernando Santoro, que atualmente é professor da Escola de Comunicações e Artes da Universidade de São Paulo (ECA/USP).

${ }^{17}$ De acordo com Velho (2004 [1987]), a experiência urbana contemporânea é caracterizada pela relativa fluidez das fronteiras sociais e pela fragmentação das identidades. Algo que abre espaço para uma maior conscientização das alternativas em termos de estilos de vida. Neste sentido, a noção de "projeto" permite colocar em evidência a habilidade de diferentes atores na gestão de suas autoimagens.
} 


\section{Fórum de Experiências Populares em Audiovisual (FEPA): um divisor de águas}

O FEPA foi idealizado e organizado pelo gestor de projetos socioeducativos e diretor da ONG Imaginário Digital Márcio Blanco que, ao mesmo tempo, é até hoje o principal responsável pelo Festival Visões Periféricas, um dos maiores festivais dedicados ao gênero do chamado "Cinema de Periferia" no Brasil ${ }^{18}$.

No momento de sua fundação, em julho de 2007 no Rio de Janeiro, durante a primeira edição do referido festival, os representantes das ONGs que passaram a compor o FEPA redigiram conjuntamente uma carta à qual deram o título de "Carta da Maré”, quando anunciaram como principal objetivo da rede a ideia de instituí-la como um órgão representativo dos interesses relacionados às manifestações audiovisuais "populares" de todo o país.

Entretanto, apesar de se tratar de um fórum nacional, pretensamente representativo de todas as experiências audiovisuais relacionadas às camadas "populares", esse ato de fundação da rede ocorreu sem sequer um anúncio prévio e nem um chamamento público à participação popular. Sua organização desdobrou-se - como o próprio Marcio Blanco me revelou em entrevista ${ }^{19}$ - a partir de simples trocas de emails e contatos estabelecidos entre representantes de uma série de ONGs distribuídas pelo país. Além disso, tais desdobramentos aconteceram justamente no momento em que, como vimos, segmentos heterogêneos de pessoas ligadas a coletivos culturais independentes, formados por realizadores e exibidores de produções audiovisuais comprometidos com uma variedade de lutas sociais, estavam buscando se diferenciar das demandas e pontos de vista sustentados pelas instituições do terceiro setor, em São Paulo.

Quando as pessoas vinculadas ao recém fundado CVP ficaram sabendo das articulações relacionadas à rede FEPA, portanto, esta organização já havia sido constituída em seu primeiro encontro no Rio de Janeiro sem que, conforme mencionado, os mesmos tivessem tomado conhecimento do processo e dos objetivos que levaram à sua criação. Pouco após o lançamento da rede na capital carioca, houve uma nova reunião do FEPA, desta vez em São Paulo, durante o Festival Internacional de Curtas Metragens, organizado pela Associação Cultural Kinofórum, em agosto de 2007. O objetivo deste segundo encontro era, naquela altura, discutir uma proposta de

\footnotetext{
${ }^{18}$ Para mais informações, ver: http://imaginariodigital.org.br/visoes-perifericas (Acesso em 08/05/2017).

${ }^{19}$ Para mais detalhes sobre este processo, ver Aderaldo (2017).
} 
formalização jurídica do Fórum (obtenção de um Cadastro Nacional de Pessoa Jurídica [CNPJ]), bem como algumas ideias relacionadas à configuração de uma agenda única de ações a serem apoiadas por seus integrantes e levadas ao Ministério da Cultura (MinC).

Ao comentar esse segundo encontro da rede FEPA, ocorrido em São Paulo, já com a presença de alguns integrantes do CVP, Cirello (2010: 69-70) - que à época, ao mesmo tempo em que escrevia sua tese de doutoramento era a responsável pela organização da mostra "Formação do Olhar", dedicada à exibição de filmes realizados pelas oficinas Kinofórum dentro do Festival Internacional de Curtas Metragens - conta que os debates foram pautados por fortes divergências, especialmente relacionadas a um projeto de edital destinado ao financiamento de iniciativas "populares" de produção audiovisual que os idealizadores da rede FEPA queriam propor ao MinC.

A principal divergência nesse caso deu-se pelo fato de que os representantes de alguns dos coletivos vinculados ao CVP discordaram veementemente da ideia de que o projeto de edital proposto contemplasse somente a dimensão da "produção" de vídeos, deixando de lado os processos de "formação" e "exibição" que, para estes últimos, era algo mais importante do que o incentivo à realização de filmes pura e simplesmente, uma vez que era por meio da formação e da exibição que a popularização do conhecimento e o incentivo às trocas de informações e percepções políticas entre populações relacionadas aos espaços precários das cidades seriam estimuladas.

O conflito, portanto, revelou as posições e os princípios distintos que regiam cada uma das redes, uma vez que a principal divergência estava no fato de que, enquanto no caso do FEPA, o esforço se concentrava em torno da iniciativa de abrir espaço no mercado cultural para as produções audiovisuais entendidas como "populares" ou "periféricas", no caso da rede CVP, o interesse maior girava em torno da busca por um maior incentivo público a processos de formação que permitissem uma maior democratização do acesso ao conhecimento das técnicas de produção audiovisual para que mais coletivos e movimentos de luta popular pudessem fazer do vídeo uma ferramenta de luta política ${ }^{20}$.

\footnotetext{
${ }^{20}$ Em conversas internas entre membros do CVP era comum que os mesmos se referissem ao FEPA como sendo uma rede voltada ao desenvolvimento de "produtos", enquanto o CVP era visto como uma rede caracterizada pelo fortalecimento de "processos" políticos mais amplos.
} 
Outro ponto discutido nessa reunião, ao qual os integrantes do CVP se opuseram, foi o da citada formalização jurídica da rede FEPA, uma vez que, para os mesmos, esta iniciativa significaria, na verdade, a burocratização e hierarquização de processos e demandas de natureza política, com a finalidade de um estabelecimento prévio do consenso que destoava completamente dos princípios reivindicativos que fundamentavam suas ações e intenções, relacionadas ao uso do audiovisual junto às camadas populares.

Após esta fatídica reunião, onde as dissidências ficaram evidentes sem que nenhum acordo fosse obtido, tornou-se clara a impossibilidade de que a rede FEPA viesse a se tornar - conforme sua pretensão - uma entidade representativa de todas as demandas relacionadas ao "audiovisual popular" no país. Isso levou uma série de coletivos que vinham se formando em São Paulo, tais como Cinescadão, Cinebecos, Cinecampinho, Núcleo de Comunicação Alternativa (NCA), Brigada Audiovisual da Via Campesina (Coletivo vinculado ao MST), entre outros, à realização de reuniões regulares para a formulação de um posicionamento contrário à rede FEPA, que passava a ser vista por eles como uma entidade representativa dos interesses únicos e exclusivos de certas ONGs e do mercado cultural dominante.

A rede CVP então, passou a discutir estratégias de mobilização em uma lista de e-mails criada na internet, bem como nas referidas reuniões mensais. Neste sentido, a existência do FEPA foi uma espécie de elemento aglutinador para sua coalizão. O CVP chegou, inclusive, a realizar uma "Semana do Vídeo Popular", em 2008, onde o assunto foi largamente discutido.

No segundo semestre de 2008, também no Festival Visões Periféricas, ocorreria o terceiro encontro do FEPA. À essa altura, a rede já havia feito suas primeiras conquistas junto ao MinC, uma vez que Márcio Blanco fora convidado pela Secretaria do Audiovisual (SAV) a representar as demandas do "audiovisual popular" junto a um conselho consultivo vinculado ao órgão, o que incomodou profundamente os membros do CVP além de outros agentes, conforme veremos adiante.

A ideia de institucionalização do fórum também persistia entre a maioria de seus membros. A proposta era a de que, após tornar-se uma entidade juridicamente reconhecida, a rede FEPA poderia manter uma estrutura administrativa, onde cada estado seria reconhecido como uma "Experiência Popular Audiovisual" autônoma (uma EPA), tendo algumas pessoas previamente eleitas para representar os interesses locais 
relacionados às políticas voltadas ao audiovisual "popular" nas reuniões nacionais do fórum, o que, claramente, feria a diversidade de posicionamentos e os conflitos existentes nas distintas regiões do país ${ }^{21}$.

Neste terceiro encontro, a organização do FEPA assumiu o compromisso de enviar duas passagens a cada entidade interessada em participar do evento, na cidade do Rio de Janeiro, o que incluía o CVP. Entretanto, a partir de uma carta escrita pelos coletivos participantes desta rede e endossada pela ONG Ação Educativa, por meio de seu Centro de Mídia Juvenil (CMJ) ${ }^{22}$, a Secretaria Municipal de Cultura de São Paulo financiou um ônibus para que, além dos dois representantes que teriam as passagens pagas pela organização do FEPA, todos os demais pudessem comparecer ao evento.

A viagem ao Rio de Janeiro, contudo, para os integrantes do CVP, não tinha como objetivo a participação nas discussões do FEPA, mas sim o questionamento da legitimidade desta entidade enquanto unidade representativa dos movimentos ligados às causas populares no audiovisual brasileiro, bem como a legitimidade da própria reunião. O inevitável choque entre as posições defendidas pelo FEPA e pelo CVP - que passou a ser visto, pelos demais presentes no evento, como "o grupo dos paulistas" - novamente polarizou o debate, dessa vez com ofensas e trocas de acusações pessoais.

Como desdobramento desses conflitos, algumas instituições decidiram se retirar da rede FEPA. A primeira foi a ONG carioca Cinema Nosso $^{23}$ que, por meio de uma carta de renúncia, apontou para os motivos que faziam com que os mesmos deixassem de reconhecer o FEPA como entidade representativa. Em um dos trechos da referida carta os representantes da ONG dizem:

\begin{abstract}
(...) a última reunião presencial do FEPA, realizada durante o Festival Visões Periféricas e os últimos e-mails que acompanhamos revelaram que o fórum caminha para uma direção que o Cinema Nosso não acredita ser a mais adequada para o fortalecimento de um movimento nacional pela democratização do audiovisual (...). Discordamos veementemente de qualquer processo de formalização do fórum como instituição que, em nosso entendimento, tende a reproduzir padrões mercadológicos ou burocráticos de atuação de grandes companhias (...). Um processo deliberativo a partir de representantes regionais criaria níveis de hierarquia e poder diferenciados entre as organizações participantes, tornando a tomada de decisão menos coletiva e
\end{abstract}

\footnotetext{
${ }^{21}$ Nos termos de diversos interlocutores de pesquisa, vinculados ao CVP e também a ONGs críticas à postura da rede FEPA, esta costumava ser interpretada como uma "ONG de ONGs", ou seja, como uma organização que visava estruturar-se de modo semelhante ao de uma ONG, mas buscando representar interesses e demandas que iam além de suas condições e objetivos.

${ }^{22}$ Tratava-se de um setor desenvolvido para atuar com a área de educação audiovisual junto ao público atendido pela instituição que é uma das entidades que conta com maior credibilidade entre os jovens interlocutores da pesquisa.

${ }^{23}$ Ver: http://www.cinemanosso.org.br/site/ (Acesso em 09/05/2017).
} 
transparente, mais verticalizada e questionável. O Cinema Nosso não concorda com o fato de que os representantes do FEPA, sejam eles quem forem, possam estabelecer um diálogo direto com o poder público e encaminhar propostas que as organizações, coletivos e experiências populares "representados" pouco conhecem ou desconhecem totalmente. A participação deve estar garantida por mecanismos claros e acessíveis a todos (Carta de saída do FEPA - Cinema Nosso, 2008).

Algum tempo após a volta a São Paulo, o CVP também decidiu elaborar uma carta de renúncia ao FEPA, em moldes semelhantes àquela escrita pelo Cinema Nosso, uma vez que a rede havia sido integrada como uma das entidades participantes deste fórum que aceitaram fazer parte de sua lista de e-mails e das reuniões. Para isso pediram o apoio de importantes instituições do terceiro setor, como a Ação Educativa e o Instituto Pólis ${ }^{24}$ que, através de membros de suas administrações, decidiram assinar a carta, onde lemos passagens como:

(...). Ingressamos no FEPA justamente interessados em nos inteirar das discussões, acreditando que poderíamos colaborar com uma construção coletiva. Consideramos fundamental a ideia de um espaço no qual fossem levantadas e discutidas as propostas de um movimento, com e pelos seus autores sociais. Isso, com ênfase na participação, na colaboração e na transparência. Em sintonia com a nota divulgada pelo Cinema Nosso em janeiro deste ano, não concordamos com a forma atual de representação estabelecida no FEPA, onde propostas são encaminhadas sem que tenham sido amplamente debatidas com seus integrantes. Acreditamos que o vídeo popular é um trabalho que se estabelece na base com uma atuação social marcada por seus próprios atores. Nossa realidade não pode ser homogeneizada e transformada em uma única organização com um representante institucional (Carta de saída do FEPA - CVP, 2009).

Outra instituição que se retirou do FEPA foi a Associação Cultural Kinofórum, igualmente através de carta, o que enfraqueceu consideravelmente o fórum, obrigando a que os representantes do mesmo escrevessem respondendo às associações que se retiraram, através de um documento onde reconheciam alguns erros e buscavam um meio de conciliação. Algo que, por fim, não teve resultados práticos.

\footnotetext{
${ }^{24}$ Ver: http://polis.org.br (Acessado em 08/05/2017).
} 


\section{Da crise à retomada}

Foi neste momento, após o retorno do Rio de Janeiro e durante o processo de elaboração da carta de renúncia ao FEPA, em 2009, que passei a acompanhar regularmente as reuniões do CVP, bem como ingressei em sua lista de e-mails, o que me permitiu seguir as discussões de forma mais detida. Naquela altura as reuniões presenciais da rede ocorriam uma vez ao mês em diferentes lugares e o comparecimento de seus integrantes oscilava consideravelmente. Havia encontros bastante esvaziados e outros com um número considerável de pessoas.

O perfil dos membros do $\mathrm{CVP}^{25}$, como já adiantei, era bastante heterogêneo. Embora majoritariamente formado por agentes ligados a coletivos que realizam produções e exibições audiovisuais nas diversas regiões periféricas da cidade, também havia aqueles que utilizavam o vídeo em projetos pedagógicos desenvolvidos em escolas, como é o caso do Coletivo Nossa Tela ${ }^{26}$, além de integrantes de movimentos sociais como o MST (Movimento dos Trabalhadores Rurais Sem Terra), que participavam das reuniões através do coletivo Brigada Audiovisual da Via Campesina, o setor de mídia onde os vídeos próprios do movimento são editados e discutidos.

Outra presença marcante era a de pessoas que não atuavam diretamente em nenhum coletivo, como Vanessa Reis, Luiz Barata e Luís Eduardo Tavares, que naquele momento trabalhavam, respectivamente, nas ONGs Associação Cultural Kinofórum, Ação Educativa e Instituto Pólis, onde cumpriam a função de gestores de espaços destinados, entre outras coisas, aos cuidados com projetos na área audiovisual. No contexto das reuniões, porém, tais participações ocorriam sem que os mesmos representassem as instituições onde trabalhavam, posto que havia diferenças de princípios e objetivos consideráveis entre a postura do CVP e destas organizações.

No caso de minha participação junto às reuniões da rede, a condição de pesquisador nunca foi considerada um problema ${ }^{27}$, embora desde o início tenha ficado acordado que, quando solicitado, eu deveria contribuir com a participação em algumas atividades, como o auxílio na realização e organização de eventos. Assim o fiz. Escrevi

\footnotetext{
${ }^{25}$ Restrinjo-me às pessoas que conheci presencialmente nas reuniões.

${ }^{26}$ O Coletivo Nossa Tela é um coletivo de vídeo, surgido em 2006, cuja principal forma de atuação consiste na elaboração de processos de produção, exibição e formação em audiovisual, principalmente em escolas.

${ }^{27}$ Em grande medida isso se deveu ao fato de eu ter chegado até o CVP somente após contatos anteriores com alguns de seus integrantes, tendo sido apresentado à rede por essas pessoas. Para mais detalhes a respeito dessa entrada, ver Aderaldo (2016; 2017).
} 
algumas atas de reuniões, envolvi-me na organização de um circuito de vídeos e, em alguns momentos, trouxe questões a serem discutidas por todos, buscando problematizar alguns posicionamentos que costumavam aparecer nos encontros ${ }^{28}$.

Nas primeiras reuniões que acompanhei, no início de 2009, as conversas eram praticamente monopolizadas pelo debate relacionado à postura formal que o Coletivo de Vídeo Popular deveria adotar em relação ao FEPA, de modo que acompanhei todo o processo de elaboração da supracitada "carta de saída" desta rede que, conforme já argumentado, caracteriza-se pelo vínculo com uma diversidade de ONGs comprometidas com projetos de "educação audiovisual” em todo o país.

Outra questão que acompanhei de perto, nas reuniões e na lista de discussões na internet, foi o processo de elaboração dos projetos realizados pela rede para concorrer ao edital VAI, que conquistaram por dois anos seguidos (2009-2010 e 2010-2011). A intenção dos projetos era possibilitar a obtenção de recursos públicos para o financiamento das quatro principais ações do CVP, que eram, respectivamente:

1. A publicação de uma revista contendo reflexões dos membros da rede, bem como entrevistas realizadas por estes, junto a personalidades relacionadas ao universo do vídeo popular e das lutas sociais;

2. A organização de pacotes temáticos de DVDs com o conteúdo das produções elaboradas pelos coletivos integrantes, os quais seriam enviados a escolas, sedes de movimentos sociais, universidades, bibliotecas comunitárias, etc;

3. A realização de um circuito de exibição itinerante dessas mesmas produções em uma série de espaços marginalizados ou subaproveitados da cidade;

4. A organização e realização de uma Semana do Vídeo Popular, com convidados, com o intuito de promover debates relacionados às questões trazidas pelo CVP.

Essas ações eram as principais responsáveis por fazer com que tantos coletivos integrassem a rede (mais de quarenta, como diziam na carta de renúncia ao FEPA), apesar de, conforme dito, pouquíssimas pessoas participarem das reuniões presenciais. A imensa maioria dos coletivos participantes apenas atuava nas discussões da internet;

\footnotetext{
${ }^{28}$ Conforme cita Marc Augé: "Os antropólogos não foram sempre inocentes, sempre participaram dos fenômenos que estudam. Por outro lado, as pessoas não querem ser observadas como leões em jaulas ou formigas trabalhadoras. A única maneira de superar este dilema é pela tomada de consciência de que compartilhamos os mesmos problemas e que vamos estudá-los em tal ou tal contexto, o que deve ser explicitado" (Augé, 1998: 118).
} 
também enviavam suas produções para integrarem os pacotes de DVDs e exibiam os filmes do circuito em suas respectivas áreas; o que provocou certas crises e discussões entre àqueles que costumavam se colocar na "linha de frente" da rede, fosse dando seus nomes como proponentes e membros da equipe técnica junto aos projetos elaborados para concorrer a editais como o VAI, fosse participando ativamente das reuniões presenciais e redigindo as atas, que depois circulavam na lista on line.

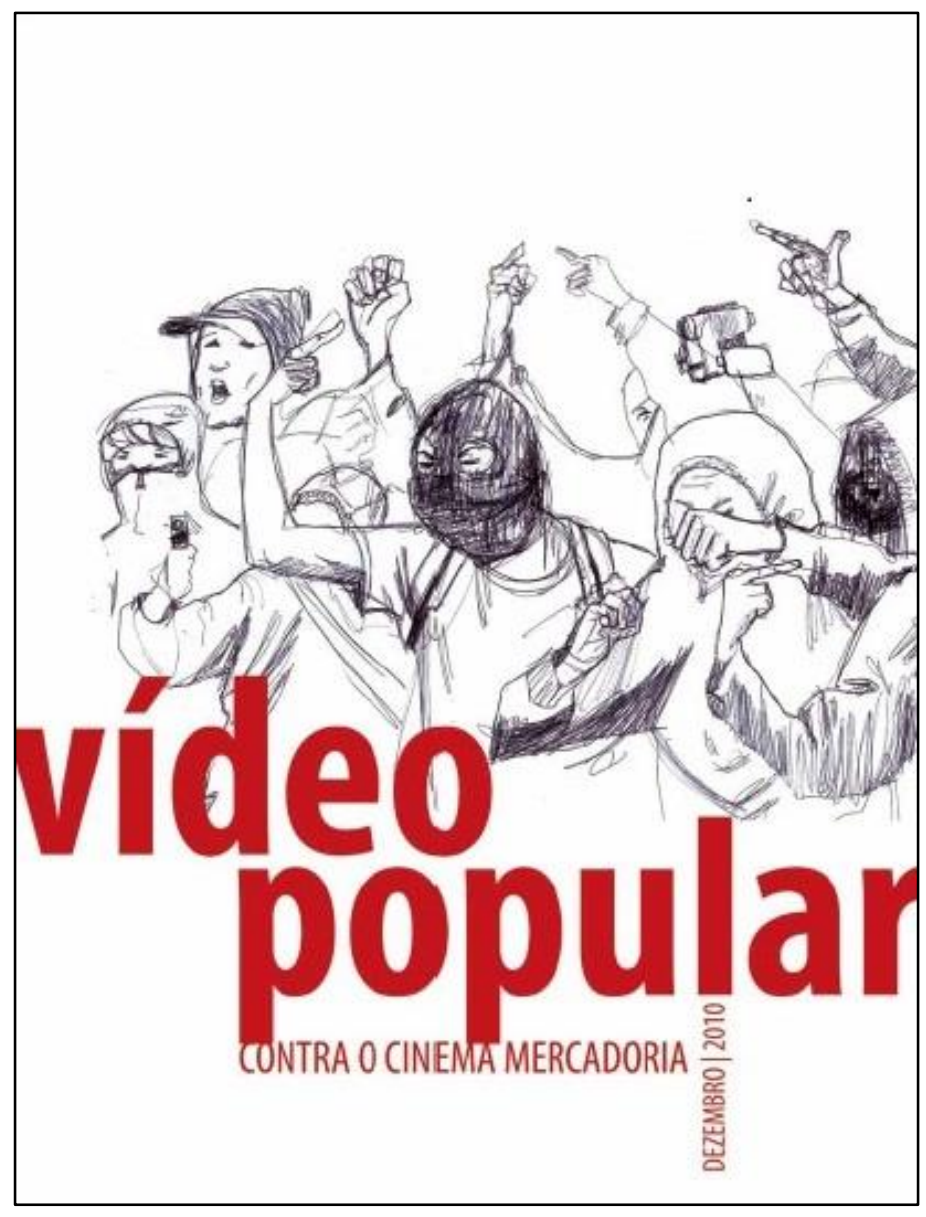

Figura 1: Revista Vídeo Popular, № 5, 2010.

Tais crises se agravaram após o convite feito por parte da Secretaria do Audiovisual (SAV), ligada ao MinC, para que fosse escolhido, entre os membros do CVP, um representante que viesse a fazer parte do mesmo conselho consultivo do qual Márcio Blanco havia participado no órgão, como representante do FEPA e que, conforme dito, tinha a função de auxiliar no desenvolvimento de políticas públicas para o setor. 
O convite gerou grandes discussões internas. Havia aqueles que eram totalmente contrários à participação formal do CVP na SAV e outros que eram favoráveis. Após decidirem que iriam participar das reuniões do referido conselho - que ocorreriam em Brasília em períodos definidos pelo MinC -, um outro dilema se deu em torno dos nomes que poderiam ser escolhidos para representá-los. Numa primeira consulta foram indicados quatro nomes. A proposta do CVP era a de que a cada reunião do órgão consultivo da SAV houvesse um rodízio na participação das pessoas vinculadas à rede; algo prontamente negado pela SAV que, por sua vez, sugeriu a escolha de Vanessa Reis (que havia sido um dos nomes indicados pelo CVP) como representante. Isso mobilizou novas discussões nas reuniões pois, enquanto alguns não viam problemas no fato dela representar a todos na condição de pessoa física nos encontros da SAV, outros consideravam uma perda de força política ter justo alguém diretamente ligado a uma ONG como única representante do Coletivo de Vídeo Popular ${ }^{29}$.

Houve debates acalorados no período. Algumas pessoas deixaram de participar dos encontros do coletivo, outras ingressaram nas reuniões. Havia ainda os que apoiavam a ideia de que o diálogo direto com o poder público fosse totalmente abandonado e os que, contrariamente, pontuavam a importância de uma compreensão acerca de "como as coisas funcionam por dentro" de instituições como a SAV.

Por fim, Vanessa foi escolhida como representante, mas a participação junto ao conselho da SAV não durou muito. Após a presença em algumas poucas reuniões do órgão o CVP encerrou sua participação sem grandes conquistas. Neste período houve um aprofundamento da crise interna entre seus membros, o que fez com que alguns dos integrantes decidissem organizar dois dias de encontros e discussões para uma reavaliação da rede, com vistas à reformulação de seus princípios e formas de atuação.

Durante os encontros, que aconteceram no Sacolão das Artes ${ }^{30}$ no fim de 2010 e contaram com a presença de convidados ${ }^{31}$, muitos assuntos foram discutidos e, por fim, houve um acordo geral no sentido de que a finalidade da rede a qual pertenciam não deveria ser a defesa de uma identidade de grupo fixa e homogênea, passível de figurar

\footnotetext{
${ }^{29}$ Conforme dito, naquele momento Vanessa trabalhava na ONG Associação Cultural Kinofórum.

${ }^{30}$ Trata-se de uma "ocupação cultural" promovida por distintos coletivos e movimentos sociais da região do Parque Santo Antônio, no extremo sul de São Paulo. Para mais detalhes, consultar: http://sacolaodasartes.blogspot.com.br/ (Acessado em 20/05/2017).

${ }^{31}$ Entre os convidados estavam profissionais da TVT. Uma rede de televisão vinculada ao Sindicato dos Metalúrgicos do ABC e ao Sindicato dos Bancários de São Paulo, Osasco e região. Deste encontro, inclusive, surgiu um convite para que o CVP administrasse um programa onde seus vídeos seriam exibidos e debatidos no canal. Algo que se consolidou, chegando a durar cerca de um ano.
} 
como uma nova opção no mercado audiovisual hegemônico, mas sim a busca da ampliação da visibilidade pública das demandas políticas por trás das ações de diferentes movimentos de luta popular. Mais do que usar a cidade e sua paisagem segregada como cenário para a produção de filmes com uma etiqueta identitária "periférica", portanto, o que os integrantes do CVP desejavam, ao menos naquele momento, era utilizarem as ferramentas audiovisuais como instrumentos de sensibilização política para as causas populares.

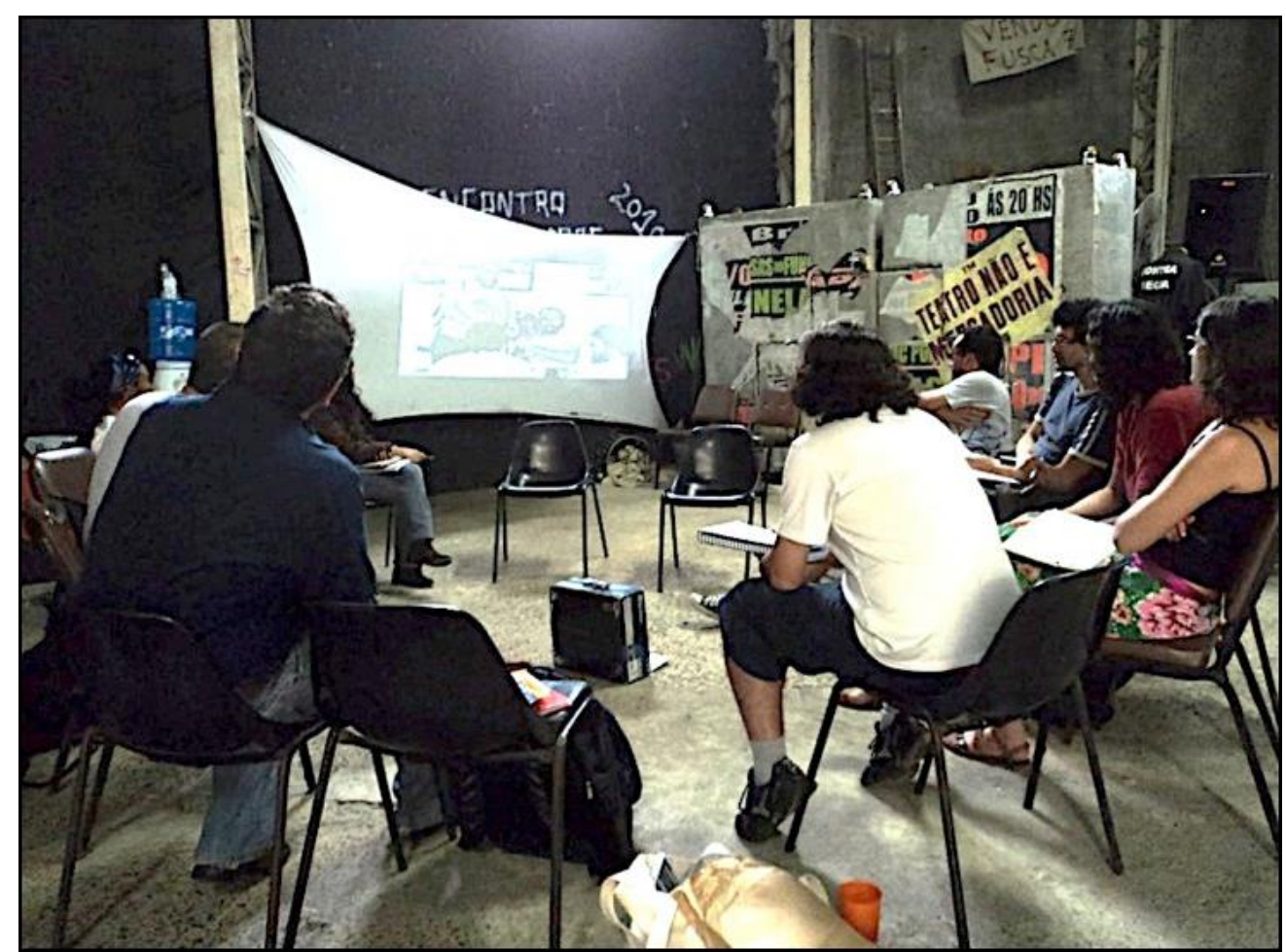

Figura 2: Reunião do CVP no Sacolão das Artes, 2010 (Créditos: Guilhermo Aderaldo).

Como primeira estratégia de ação neste sentido, foi sugerida a possibilidade de uma reconfiguração do circuito de exibição audiovisual organizado pela rede que, até aquele momento, se limitava à distribuição de pacotes com DVDs das produções dos coletivos que a constituíam e que eram exibidas de acordo com o desejo e as datas escolhidas por cada uma dessas associações.

A ideia era a de que, dali em diante, fossem escolhidos dois filmes a cada dois meses para que os mesmos pudessem "entrar em cartaz" - como diziam, buscando construir, de forma irônica, uma relação com o cinema comercial - sendo exibidos durante este período, cada semana em um lugar. Para os presentes na reunião, tal iniciativa favoreceria uma maior integração entre os coletivos e tornaria necessário o 
deslocamento das pessoas interessadas em acompanhar o circuito, por uma série de espaços não legitimados pelo poder público (favelas, assentamentos, ocupações), ou subutilizados pelas administrações municipais (CEUs ${ }^{32}$, escolas públicas), possibilitando, a partir da exibição dos filmes, a criação de espaços para uma crítica mais radical das relações de poder na cidade.

Em 2011, acompanhei este circuito em diversos lugares. Os filmes escolhidos para inaugura-lo foram: "Qual Centro?" (Nossa Tela, 2010, 15min) ${ }^{33}$, que aborda a questão da especulação imobiliária na região central de São Paulo a partir do ponto de vista dos movimentos de luta por moradia e "Fulero Circo" (Cia. Estudo de Cena, 2010, $50 \mathrm{~min})^{34}$, que, por meio da história de uma trupe de artistas formada por desempregados e trabalhadores ocasionais que viajam o país para apresentar uma peça onde retratam as condições que geraram seu estado de pauperização, tematiza a diminuição do espaço para a política de base popular e reivindicativa no mundo contemporâneo, dominado pelo receituário neoliberal.

Em cada um dos locais onde os filmes eram exibidos, as discussões ganhavam características muito particulares, estimulando trocas de opiniões e vínculos de solidariedade diversos. Tais experiências, como pude constatar ao longo da investigação, trouxeram para os membros do CVP uma condição privilegiada para conhecerem, de forma mais apurada, a cidade e as relações de poder que atravessam sua paisagem segregada. Pouco a pouco, o léxico tradicionalmente utilizado pelas instituições do terceiro setor para caracterizar as periferias urbanas como algo circunscrito aos limites de determinados espaços geográficos fixos, foi dando lugar a um novo esquema interpretativo, que entende a "periferia" como uma relação (móvel/itinerante), caracterizada por uma situação de acesso desigual a direitos. Mais do que um "produto", portanto, a periferia passava a ser entendida por esses atores como um termo responsável por nomear um "processo" que envolve os perversos efeitos por trás dos modelos político e urbanístico hegemônicos. Tratar-se-ia, assim, de um fenômeno passível de ser visto em toda a cidade e não apenas nas suas margens.

\footnotetext{
32 Referência aos Centros Educacionais Unificados (CEUs). Para maiores detalhes, consultar: http://portal.sme.prefeitura.sp.gov.br/Main/Page/PortalSMESP/CEUs--Enderecos (Acessado em 25/05/2017).

${ }^{33}$ O filme pode ser integralmente visto no seguinte link: https://vimeo.com/29499649 (Acessado em 25/05/2017).

${ }^{34} \mathrm{Um}$ pequeno trecho do filme, pode ser visto em: https://www.youtube.com/watch?v=1X2zh6fvWOY (Acessado em 25/05/2017).
} 


\section{Considerações Finais}

O exemplo do CVP e sua complexa tentativa de consolidar uma rede descentralizada e autogestionária de realizadores de vídeos politicamente engajados e integrados em torno de coletivos relativamente autônomos na cidade de São Paulo, permite-nos enxergar, entre outras coisas, o modo pelo qual dispositivos de comunicação vem sendo utilizados como ferramentas políticas nos atuais contextos urbanos.

Conforme vimos, a rede CVP formou-se a partir de vínculos e formas de solidariedade que foram sendo estabelecidos entre pessoas com perfis heterogêneos, embora igualmente identificadas com o desejo de suplantarem um conjunto de representações normativas, decorrentes da gestão de certas ONGs, setores do governo e empresas baseadas no princípio da "responsabilidade social".

A principal crítica partilhada pelos coletivos e atores presentes no processo de formação do CVP foi a de que nas reuniões, cursos e eventos dos quais costumavam participar naquele momento, noções como "Cinema de Periferia", "Cinema de Favela" ou "jovem de periferia", passaram a operar como dispositivos responsáveis pela imposição de certos critérios administrativos de uma larga conjuntura de instituições do "terceiro setor" junto às populações entendidas como seu "público alvo".

Na visão de pessoas como Diogo Noventa, por exemplo, tais critérios tenderiam a considerar as populações eventualmente atendidas pelas ONGs não como sujeitos políticos em busca de direitos, mas como meros grupos de interesse a serem adicionados a uma estrutura política e cultural pré-existente, o que fazia com que, não raro, o conceito de "periferia" acabasse por ser tomado como uma espécie de eufemismo da noção de “classe social”, levando, por conseguinte, questões políticas mais complexas e abrangentes a serem substituídas por interesses centrados na suposta especificidade cultural dos chamados "artistas da periferia"35. Desta maneira, a linguagem institucional de muitas ONGs tendia a fazer com que discussões políticas mais agudas sobre o problema da desigualdade urbana fossem substituídas por uma busca de maior "diversidade" nas produções audiovisuais hegemônicas. Algo que estimulava todo um mercado cultural voltado às chamadas "produções culturais

\footnotetext{
${ }^{35}$ Para uma crítica mais detida sobre a economia moral relacionada à atuação das ONGs voltadas ao desenvolvimento de projetos de "arte-educação" junto a camadas socialmente desfavorecidas, ver, por exemplo, Souza (2008); De Tommasi (2013) e Rocha (2015).
} 
periféricas" sem que isso necessariamente acarretasse numa problematização mais efetiva das relações de poder envolvidas com esse mercado.

Tal postura, fortemente criticada pelos integrantes do CVP, foi amplamente evidenciada com o surgimento da rede FEPA, em 2007, quando diversas instituições relacionadas a cursos e oficinas voltados à chamada "educação audiovisual popular" (Cirello, 2010) associaram-se com a finalidade de montarem uma organização com abrangência nacional, cuja função seria, claramente, a de filtrar demandas relacionadas às mobilizações "populares" no campo audiovisual, com o objetivo de levar propostas pré-elaboradas de políticas públicas às distintas instâncias governamentais dedicadas à área da cultura.

Ao perceberem o modo como determinados interesses privados (relacionados à concepção gestionária de certas organizações não governamentais) estavam sendo mobilizados em torno de questões públicas no campo audiovisual, os coletivos e pessoas ligados à recém surgida rede CVP fortaleceram ainda mais seus vínculos, fazendo transparecer na arena pública o descontentamento de uma parcela considerável de pessoas - sobretudo jovens trabalhadores precários nas chamadas "profissões criativas" - com relação a certas apropriações estéticas especialmente relacionadas à interpretações mais instrumentais do termo "periferia" às quais vinham sendo estimuladas por este novo "mercado da cultura".

É possível, portanto, ponderarmos que o conflito entre as redes CVP e FEPA nos permite compreender de forma mais aguçada, a maneira pela qual surgem e se desenvolvem posicionamentos dissidentes em torno de uma série de dilemas envoltos na problemática conceituação de identidades culturais no atual mundo hipermediatizado em que vivemos.

Conforme busquei demonstrar, os jovens que integram boa parte dos coletivos que participaram do processo de formação e consolidação da rede CVP no período da pesquisa, embora, em sua maioria, tenham nascido e crescido em regiões marcadas por significativos processos de precarização sócio urbana, passam longe de corresponderem às imagens opacas dos "jovens vulneráveis", "excluídos" ou dos famosos "jovens de projeto" que muitas vezes preenchem os discursos dos agentes institucionais. Tratam-se, na verdade, de pessoas com considerável acúmulo de experiências profissionais/educativas e com enorme capacidade reflexiva, às quais, na medida em que passaram a se apropriar "taticamente" (De Certeau, 1994 [1980]) dos meios de 
produção de representações, consequentemente, também começaram a disputar intelectual e politicamente com ONGs, entidades filantrópicas, jornalistas, pesquisadores, entre outros agentes, a própria forma de interpretar os sentidos da atual desigualdade urbana brasileira.

Assim, é possível dizer que o uso dos novos meios comunicativos, ao menos nesse caso, se desdobrou, para muitos desses jovens interlocutores, numa forma para que os mesmos pudessem, ao invés de simplesmente reivindicar o "reconhecimento" (Fraser, 2007) de uma identidade cultural "periférica" (fixa e homogênea), lutar pela retomada do direito de se configurarem, de forma complexa, como sujeitos com voz ativa, voltados a intervir de maneira decisiva nos processos de interpretação e produção da própria cidade.

\section{Referências}

ADERALDO, Guilhermo. Reinventando a cidade: uma etnografia das lutas simbólicas entre coletivos culturais vídeo-ativistas nas "periferias" de São Paulo. São Paulo: Annablume/Fapesp, 2017.

. "Entre imagens e imaginários: estética e política nas intervenções visuais/audiovisuais de coletivos culturais paulistanos" em: Pluralidade urbana em São Paulo: vulnerabilidade, marginalidade, ativismos sociais. Organizado por Kowarick, Lúcio e Frúgoli Jr, Heitor. São Paulo: Editora 34, 2016, pp. 55-79.

ADERALDO, Guilhermo e RAPOSO, Otávio. "Deslocando fronteiras: notas sobre intervenções estéticas, economia cultural e mobilidade juvenil em áreas periféricas de São Paulo e Lisboa", Horizontes Antropológicos, 45 | 2016, pp. 279-305.

AGIER, Michel. L'invention de la ville. Paris: Archieves contemporaines, 1999.

Antropologia da cidade: lugares, situações, movimentos, São Paulo:

Terceiro Nome, 2011 [2009].

Découverte, 2013.

La condition cosmopolite: lépreuve du piège identitaire, Paris: La

AUGÉ, Marc. Por uma antropologia da mobilidade. Maceió: Edufal/Unesp, 2010a.

$2010 \mathrm{~b}$.

Pour une anthropologie des mondes contemporains. Paris: Flammarion,

Paulo, 1998, pp. 112-121.

"Agora somos todos contemporâneos" Entrevista in: Sexta Feira N 3, São

BECKER, Howard (2008 [1963]). Outsiders: estudos de sociologia do desvio, Rio de Janeiro: Zahar, 2008 [1963].

CABANES et al. (Orgs). Saídas de emergência: ganhar, perder a vida na periferia de São Paulo, São Paulo: Boitempo, 2011.

CANCLINI, Nestor Garcia; CRUCES, Francisco e POZO, Maritza (Orgs.). Jóvenes, culturas urbanas y redes digitales. Barcelona: Ariel, 2012.

CASTELLS, Manuel. Redes de indignação e esperança: movimentos sociais na era da internet, Rio de Janeiro: Zahar, 2013.

CEFAI, Daniel; VEIGA, Felipe B. e MOTA, Fábio R. "Arenas públicas: por uma etnografia da vida associativa", In: CEFAI et al. (Orgs). Arenas públicas: por uma etnografia da vida associativa, Niterói, EDUFF, 2011, pp. 9- 66.

CIRELLO, Moira. "Educação audiovisual popular no Brasil - Panorama 1990 - 2009". Tese de doutorado (Comunicações), Universidade de São Paulo, 2010. 
COELHO, Teixeira (Org.). A cultura pela cidade. São Paulo: Iluminuras, 2008.

CORDEIRO, Graça Í. "De minoria étnica a maioria linguística. Metamorfoses do sentido de 'português' em Massachusetts (séc. XX-XXI)". Antropolítica Revista Contemporânea de Antropologia, Programa de Pós-Graduação em Antropologia, Universidade Federal Fluminense, n. 32, 2012, pp. 19-40.

DEBERT, Guita Grin. "A dissolução da vida adulta e a juventude como valor". Horizontes antropológicos, Porto Alegre, v. 16, n. 34, Dezembro, 2010, pp. 49-70.

DE CERTEAU, Michel. A invenção do cotidiano. Vol 1. Artes de fazer, Rio de Janeiro: Vozes, 1994 [1980].

DE TOMMASI, Lívia. "Tubarões e peixinhos: histórias de jovens protagonistas". Educação e Pesquisa. São Paulo, Vol. 40, n2. 2013, pp 533-547.

"Culto da performance e performance da cultura: os produtores

culturais periféricos e seus múltiplos agenciamentos". Revista Crítica e Sociedade, 5 (2), 2016. Disponível em: <http://www.seer.ufu.br/index.php/criticasociedade/article/view/34838> FASSIN, Didier. "Compaixão e Repressão: A Economia Moral das Políticas de Imigração na França", Ponto Urbe [Online], 15|2014, posto online no dia 30. Dezembro 2014, URL: http://pontourbe.revues.org/2467 ; DOI : 10.4000/pontourbe.2467.

FELTRAN, Gabriel. Fronteiras de tensão: política e violência nas periferias de São Paulo, São Paulo: Unesp/Centro de Estudos da Metrópole, 2011.

FOOTE-WHYTE, William. Sociedade de esquina: a estrutura social de uma área urbana pobre e degradada. Rio de Janeiro: Jorge Zahar, 2005 [1943].

FRASER, Nancy. "Reconhecimento sem ética?" In: Revista Lua Nova, São Paulo, no 70, 2007, pp. 101-138 .

FRÚGOLI JR., Heitor. "O urbano em questão na antropologia: interfaces com a sociologia". Revista de Antropologia, São Paulo, v.48, n.1, 2005, pp.133-165.

. Sociabilidade Urbana. Rio de Janeiro: Zahar, 2007.

HALL, Stuart Da diáspora: identidades e mediações culturais, Belo Horizonte: UFMG, 2009 [2003].

HAMBURGER, Esther "Políticas da representação: ficção e documentário em Ônibus 174". In: MOURÃO, Maria Dora e LABAKI, Amir (Orgs), O cinema do real, São Paulo: Cosac Naify, 2005, pp. 196-215.

"Violência e pobreza no cinema brasileiro recente: reflexões

sobre a ideia de espetáculo". Novos Estudos Cebrap, São Paulo, n 78, 2007, pp. 113-128.

MARQUES, Eduardo (Org). A metrópole de São Paulo no século XXI: Espaços, heterogeneidades e desigualdades. São Paulo: Unesp, 2015.

MESQUITA, André. Insurgências Poéticas: arte ativista e ação coletiva. São Paulo: Annablume, 2011.

NÚCLEO DE COMUNICAÇÃO ALTERNATIVA (NCA). In: ASSOCIAÇÃO CULTURAL KINOFÓRUM. Vi Vendo : Oficinas Kinofórum de Realização Audiovisual, São Paulo : Ed. Kinofórum, 2012, pp.98-99.

PEREIRA, Alexandre Barbosa. "Pichando a cidade: apropriações 'impróprias' do espaço urbano" In: MAGNANI, José Guilherme e SOUZA, Bruna Mantese de (Orgs.). Jovens na metrópole: etnografias de lazer, encontro e sociabilidade. São Paulo: Terceiro Nome, 2007.

ROCHA, Lia de Mattos. "O 'repertório dos projetos sociais': política, mercado e controle social nas favelas cariocas", in: Birman et all (Orgs) (2015). Dispositivos urbanos e a trama dos viventes: ordens e resistências, Rio de Janeiro, Ed. FGV, 2015. pp. 319-341.

SARAIVA, C. e MARQUES, E. "Favelas e periferias nos anos 2000". In: KOWARICK, L. e MARQUES, E. (Orgs). São Paulo: novos percursos e atores, sociedade, cultura e política, São Paulo: 34, 2011, pp. 105- 130.

SÃO PAULO: SECRETARIA MUNICIPAL DE CULTURA (Org.). VAI 5 anos. São Paulo: Prefeitura Municipal de São Paulo, 2008.

SÃO PAULO: SECRETARIA MUNICIPAL DE CULTURA DE SÃO PAULO. Via VAI: percepções e caminhos percorridos. São Paulo: Prefeitura Municipal de São Paulo, 
2012.

SCOTT, Joan. "A invisibilidade da experiência". Projeto História. Revista do Departamento de História da Pontifícia Universidade Católica de São Paulo, no 16. São Paulo, 1998 [1991], pp. 297-325.

SERPA, Angelo. Lugar e mídia. São Paulo, Ed. Contexto, 2011.

SHOHAT, Ella e STAM, Robert. Crítica da imagem eurocêntrica. São Paulo: Cosac Naify, 2006 [1994].

SILVA, Mario A. M. A descoberta do insólito: literatura negra e literatura periférica no Brasil (1960-2000). Rio de Janeiro, Ed. Aeroplano, 2013.

SOTOMAIOR, Gabriel De Barcellos. Cinema militante, videoativismo e vídeo popular: a luta no campo do visível e as imagens dialéticas da história. Tese de doutorado (Multimeios) Universidade Estadual de Campinas, 2014.

SOUTO, Anna L. S. e ALMEIDA, Elmir (2000). Jovens, políticas públicas, mercado de trabalho. São Paulo: Pólis.

SOUZA, Regina Magalhães de. O discurso do protagonismo juvenil. São Paulo, Ed. Paulus, 2008.

TELLES, Vera Silva. "Mutações do trabalho e experiência urbana". Tempo Social, v. 18, São Paulo, 2006, pp. 173-195.

VALLADARES, Lícia P. (2005). A invenção da favela: do mito de origem à favela.com, Rio de Janeiro, Ed. FGV, 2005.

. "Educação e mobilidade social nas favelas do Rio de Janeiro: O caso dos universitários Vol. 2, Rio de Janeiro, 2010, pp. 153-172.

VELHO, Gilberto. Individualismo e cultura: notas para uma antropologia da sociedade contemporânea. Rio de Janeiro, Ed. Zahar, 2004 [1987].

YÚDICE, George. A conveniência da cultura: usos da cultura na era global. Belo Horizonte: Editora UFMG, 2013.

Recebido: 29/05/2017.

Aprovado: 28/06/2017. 